\title{
BACTERIAL CONTAMINATION OF NIGERIAN CURRENCY NOTES CIRCULATING WITHIN SELECTED MARKETS IN KADUNA METROPOLIS
}

\author{
${ }^{1}$ Musa, F.M., ${ }^{1}$ Orukotan, A.A.., ${ }^{1}$ Hassan R. A. and ${ }^{2}$ Mohammed - Idris, Z.K. \\ ${ }^{1}$ Department of Microbiology, Faculty of Science, Kaduna State University. Kaduna, Nigeria. \\ ${ }^{2}$ Department of Community Medicine, College of Medicine, Kaduna State University, Kaduna, Nigeria. \\ *Corresponding author: fmmusa1@gmail.com, 08027473126.
}

\begin{abstract}
A study was carried out with the aim to assess the bacterial contamination of Nigerian currency notes circulating within selected markets in Kaduna Metropolis. A total of 80 samples of Nigerian currency notes of different denominations were randomly collected from Sabo, Kakuri, Kawo, Dattawa, U/rimi, Kasuwar Sati, Nassarawa, Chechenia, Kasuwar barci and Kasuwar Laraba markets in sterilized polythene bags The mean bacterial counts of the different currency notes were determined using standard microbiological methods. The types of bacteria associated with the currency notes and their frequency of occurrence were also determined using standard methods. The result of the study showed that lower denomination currencies had higher microbial loads, $22.65 \times 10^{4} \pm 0.22 \times 10^{4} \mathrm{CFU} / \mathrm{g}$ for $\mathrm{N100}, 26.55 \times 10^{4} \pm 0.45 \times 10^{4} \mathrm{CFU} / \mathrm{g}$ for $\mathrm{A50}$, $20.95 \times 10^{4} \pm 0.26 \times 10^{4} \mathrm{CFU} / \mathrm{g}$ for $=\mathrm{N} 20,21.75 \times 10^{4} \pm 0.35 \times 10^{4} \mathrm{CFU} / \mathrm{g}$ for $=\mathrm{N} 10$ and $21.75 \times 10^{4} \pm 0.12 \times 10^{4} \mathrm{CFU} / \mathrm{g}$ for N5 which were mostly obtained from Kakuri, Sabo, Nasarawa, and U/Rimi markets The species of bacteria isolated from the currencies were Staphylococcus aureus (52.2\%), Escherichia coli (31.3\%), Salmonella species (11.9\%), and Proteus species (4.5\%). Staphylococcus aureus was the most predominant bacteria isolated. This study revealed that currency notes collected from the markets within Kaduna Metropolis, were highly contaminated with different pathogenic bacteria thus, calls for public awareness on the potential risks associated with poor handling of currency notes at all levels.

Key words: Bacterial contamination, currency notes, selected markets, Kaduna Metropolis
\end{abstract}

\section{INTRRODUCTION}

A paper currency is universally adopted as a medium of exchange (Olise and Simon, 2018; Okwa and Bello, 2016; Michael, 2013; Xu et al., 2012). Currencies are usually handled with bare hands and may serve as vehicles for transmission of pathogenic microorganisms like other inanimate objects (fomites) (Olise and Simon, 2018; Mukharjee et al. 2017).

A paper currency provide a large surface which may serve as breeding ground for pathogens (Michael, 2013). This is evident from previous studies carried out on microbial contamination of currencies by viruses, bacteria, protozoa and fungi (Okwa and Bello, 2016; Kuria et al., 2009; Prasai et al., 2008; Uneke and Ogbu, 2007).

Staphylococcus and spore-forming bacilli were reported to be the most predominant bacteria associated with currency notes and are often transmitted among persons either directly, through hand-to-hand contact, or indirectly, through water and food (Okwa and Bello, 2016; This may lead to potential sources of outbreaks of diseases, caused by enteric pathogens that are normally spread via the fecal-oral routes (Alemu, 2014).
Xu et al., 2012). Other pathogens isolated from currency notes as reported by Debajit et al. (2012), were species of Mycobacterium, Salmonella, Escherichia coli, Klebsiella, Streptococcus, Vibrio and Pseudomonas.

Factors influencing the persistence of microorganisms on currency notes are, population of microorganisms and their survival on surfaces, counting of currency notes by users with saliva, improper hand washing especially after using the toilets, sneezing and coughing on hands leading to contamination of currencies and transmission of microorganisms to other users (Kramer et al., 2013). Others are, the quality of materials used to produce the notes and the duration of storage conditions which together with other environmental conditions may influence the load of microbial contamination (Michael, 2013). Previous reports showed that currency notes of lower denominations are more in circulation and harbor more of the infectious agents. 
Special Conference Edition, November, 2019

Despite numerous researches conducted on microbial contamination of Nigerian currencies, none was narrowed to the markets sampled in this research. It is therefore necessary to investigate the different denominations of currencies exchanged at market places within Kaduna Metropolis with the aim to assess the presence of bacterial pathogens.

\section{MATERIALS AND METHODS}

\section{Sample Collection}

A total of 80 samples of Nigerian currency notes (Naira) handled by various classes of traders were randomly collected from ten different markets within Kaduna Metropolis. The markets were Sabo, Kakuri, Kawo, Dattawa, U/rimi, Kasuwar Sati, Nassarawa, Chechenia, Kasuwar barci and Kasuwar Laraba. The naira notes comprised of eight denominations; $\mathrm{N} 1000$, $\mathrm{A} 500, \mathrm{A200}, \mathrm{A100}, \mathrm{A50}, \mathrm{A20}, \mathrm{A} 10$ and $\mathrm{A5}$, all of each were randomly collected from each market. Each currency was exchanged in return for equal value and in some cases some items were bought from traders to obtain required currencies. Using proper aseptic technique, each trader was requested to drop a currency into a sterile polythene bag. Each bag was sealed, labeled accordingly, put in an ice box and immediately transported to the laboratory of the Department of Microbiology, Kaduna State University for further analysis. Two new mints of currency notes ( 11000$)$ were sauced from the bank and served as control notes.

\section{Sample Preparation}

Each currency note was placed aseptically using a sterilized forceps into a beaker containing $10 \mathrm{ml}$ of peptone water and then shaken for 2 minutes to wash any bacteria that adhered to the note surface. The naira note was aseptically removed and air-dried.

\section{Serial Dilutions and Inoculation of Homogenates}

This was carried out according to the method described by Mukharjee et al. (2017). About 1 $\mathrm{ml}$ from the stock solution obtained was transferred into $9 \mathrm{ml}$ of autoclaved distilled water and thoroughly mixed, then 10 -fold serial dilution of the homogenates were diluted serially from $10^{-1}$ to $10^{-5}$ dilutions. For bacterial enumeration $0.1 \mathrm{ml}$ aliquot of each dilution was pour plated in duplicates on nutrient agar plates. All plates were incubated at $37^{\circ} \mathrm{C}$ for 24 hours.

\section{Total Viable Bacterial Counts}

On establishment of growth, the number of colonies in each plate was counted by means of a digital colony counter. The microbial load was calculated as the total viable count expressed in colony forming units per currency.

\section{Isolation of Bacteria}

Isolation of bacteria was done by subculture from initial sample culture plates. Following the establishment of growth, each sample culture was examined for distinct colonies. Inocula were collected and transferred aseptically onto different selective and differential media; Eosin Methylene blue agar, Macconkey agar, Mannitol salt agar, and Salmonella - Shigella agar in plates. After incubation, the plates were examined for uniformity. The pure cultures were used for subsequent identification as it was demonstrated by Michael et al. (2013).

\section{Identification of Bacterial Isolates}

Isolates of bacteria were identified based on colony and microscopic features (extent of growth, elevation, color, pigmentation, form and edge of colonies, consistency), Gram reaction and further confirmed using standard biochemical (IMVIC) tests and microbiological test kits.

\section{Data Analysis}

Results were analyzed in form of tables. Values were statistically analyzed using one way analysis of variance (ANOVA). To compare means of naira notes, values were expressed as means \pm standard deviation and were further ranked by Waller Duncan's multiple range test. A p-value of less than 0.05 was considered significance.

\section{RESULTS \\ Determination of Viable Bacterial Counts}

The result of mean bacterial counts of the different currency denominations sampled from the different markets is presented in Table 1. All the currency notes collected showed high significant counts when compared to the control notes.

The mean bacterial counts of the different currency notes obtained from the various markets ranged between $2.25 \times 10^{4} \pm 0.35 \times 10^{4}$ $\mathrm{CFU} / \mathrm{g}-26.55 \times 10^{4} \pm 0.45 \times 10^{4} \mathrm{CFU} / \mathrm{g}$. Of the \#1000 naira notes analyzed, the highest mean count was obtained from Sabo market $\left(26.55 \times 10^{4} \pm 0.45 \times 10^{4} \mathrm{CFU} / \mathrm{g}\right.$ followed by the A1000 naira notes obtained from Kakuri, U/rimi, Chechenia and Kawo market $\left(11.85 \times 10^{4} \pm\right.$ $0.31 \times 10^{4} \mathrm{CFU} / \mathrm{g}, 10.45 \times 10^{4} \pm 0.23 \times 10^{4} \mathrm{CFU} / \mathrm{g}$, $10.05 \times 10^{4} \pm 0.25 \times 10^{4} \mathrm{CFU} / \mathrm{g}$ and $2.25 \times 10^{4} \pm$ $0.23 \times 10^{-4} \mathrm{CFU} / \mathrm{g}$ ) respectively. The highest count of A500 naira notes was from Kasuwar Laraba $\left(19.75 \times 10^{4} \pm 0.33 \times 10^{4} \mathrm{CFU} / \mathrm{g}\right)$ while the least count was from Sabo market $\left(2.25 \times 10^{4} \pm\right.$ $0.35 \times 10^{4} \mathrm{CFU} / \mathrm{g}$ ). 
Special Conference Edition, November, 2019

Furthermore, the highest count of $\$ 200$ naira notes was from Kakuri market $\left(18.25 \times 10^{4} \pm\right.$ $0.34 \times 10^{4} \mathrm{CFU} / \mathrm{g}$ ) and the least count from Sabo market $\left(9.85 \times 10^{4} \pm 0.32 \times 10^{4} \mathrm{CFU} / \mathrm{g}\right)$. Similarly, Kakuri market had the highest mean count of A100 $\left(22.65 \times 10^{4} \pm 0.22 \times 10^{4} \mathrm{CFU} / \mathrm{g}\right)$ while Chechenia market had the least count of $10.25 \times 10^{4} \pm 0.11 \times 10^{4} \mathrm{CFU} / \mathrm{ml}$. However the \#50 naira notes obtained from Sabo market had the highest mean count of $26.55 \times 10^{4} \pm$ $0.45 \times 10^{4} \mathrm{CFU} / \mathrm{ml}$ compared to the counts of high and lower denomination currencies but the mean counts of $120, \$ 10$, and $\$ 5$ naira notes were higher $\left(20.95 \times 10^{4} \pm 0.26 \times 10^{4} \mathrm{CFU} / \mathrm{g}\right.$, $21.75 \times 10^{4} \pm 0.35 \times 10^{4} \mathrm{CFU} / g$ and $21.75 \times 10^{4} \pm$
$0.12 \times 10^{4} \mathrm{CFU} / \mathrm{g}$ ) in Nasarawa, Sabo and U/Rimi markets (Table 1 ). Moreover, the differences in the mean counts of currencies analyzed, were statistically significant at $p=0.00$.

Frequency of Occurrence of Bacteria

The result of frequency of occurrence of bacteria on naira notes obtained from the various markets is presented in Table 2. Four species of bacteria, Staphylococcus aureus, Proteus, Salmonella and Escherichia coli were isolated. Of the $67(83.8 \%)$ isolates, the most frequently encountered were Staphylococcus aureus (52.2 $\%)$, followed by Escherichia coli (31.3\%), Salmonella species (11.9\%), and Proteus species (4.5\%). 
Special Conference Edition, November, 2019

Table 1: Mean Bacterial Counts of Different Currency Denominations Sampled from Different Markets

\begin{tabular}{|c|c|c|c|c|c|c|c|c|}
\hline \multirow{2}{*}{ Markets } & \multicolumn{8}{|c|}{ Currency Denominations $\left(\times 10^{4} \mathrm{CFU} / \mathrm{g}\right)$} \\
\hline & A 1000 & \# 500 & \# 200 & $\# 100$ & $\# 50$ & $\# 20$ & $\# 10$ & \#5 \\
\hline Sabo Market & $22.15 \pm 0.15$ & $2.25 \pm 0.35$ & $9.85 \pm 0.32$ & $14.42 \pm 0.25$ & $26.55 \pm 0.45$ & $13.75 \pm 0.31$ & $21.75 \pm 0.35$ & $13.75 \pm 0.32$ \\
\hline $\begin{array}{l}\text { Kawo Market } \\
\text { Dattawa }\end{array}$ & $2.25 \pm 0.23$ & $11.75 \pm 0.25$ & $13.55 \pm 0.38$ & $13.75 \pm 0.31$ & $10.75 \pm 0.30$ & $12.85 \pm 0.01$ & $7.85 \pm 0.14$ & $11.75 \pm 0.11$ \\
\hline Market & $6.35 \pm 0.30$ & $9.55 \pm 0.35$ & $13.95 \pm 0.3516$ & $12.35 \pm 0.30$ & $9.95 \pm 0.31$ & $13.65 \pm 0.28$ & $14.25 \pm 0.35$ & $14.25 \pm 0.318$ \\
\hline U/Rimi Market & $10.45 \pm 0.23$ & $15.75 \pm 0.27$ & $15.55 \pm 0.22$ & $15.05 \pm 0.33$ & $13.55 \pm 0.16$ & $16.45 \pm 0.32$ & $15.75 \pm 0.20$ & $21.75 \pm 0.12$ \\
\hline $\begin{array}{l}\text { Kasuwar Sati } \\
\text { Nassarawa }\end{array}$ & $8.15 \pm 0.22$ & $8.75 \pm 0.26$ & $16.65 \pm 0.31$ & $17.25 \pm 0.38$ & $17.85 \pm 0.27$ & $13.45 \pm 0.28$ & $16.85 \pm 0.22$ & $15.15 \pm 0.22$ \\
\hline $\begin{array}{l}\text { Market } \\
\text { Chechenia }\end{array}$ & $3.75 \pm 0.27$ & $17.55 \pm 0.35$ & $14.15 \pm 0.28$ & $13.75 \pm 0.32$ & $19.95 \pm 0.19$ & $20.95 \pm 0.26$ & $18.75 \pm 0.28$ & $17.75 \pm 0.38$ \\
\hline Market & $10.05 \pm 0.25$ & $10.05 \pm 0.27$ & $13.35 \pm 0.32$ & $10.25 \pm 0.11$ & $17.75 \pm 0.18$ & $14.55 \pm 0.20$ & $12.35 \pm 0.26$ & $16.75 \pm 0.22$ \\
\hline Kakuri Market & $11.85 \pm 0.31$ & $9.25 \pm 0.32$ & $18.25 \pm 0.34$ & $22.65 \pm 0.22$ & $16.15 \pm 0.17$ & $17.05 \pm 0.18$ & $11.75 \pm 0.31$ & $19.25 \pm 0.35$ \\
\hline Kasuwar Barci & $9.05 \pm 0.30$ & $9.75 \pm 0.34$ & $13.15 \pm 0.35$ & $13.95 \pm 0.31$ & $15.45 \pm 0.18$ & $14.55 \pm 0.327$ & $15.05 \pm 0.35$ & $18.55 \pm 0.23$ \\
\hline $\begin{array}{l}\text { Kasuwar laraba } \\
\text { Control }\end{array}$ & $9.25 \pm 0.31$ & $19.75 \pm 0.33$ & $17.35 \pm 0.28$ & $13.05 \pm 0.35$ & $15.35 \pm 0.28$ & $9.75 \pm 0.21$ & $19.65 \pm 0.12$ & $19.95 \pm 0.35$ \\
\hline$(\# 1000)$ & 0.0 & & & & & & & \\
\hline Total & $9.33 \pm 5.28$ & $11.44 \pm 4.93$ & $14.58 \pm 2.4$ & $14.68 \pm 3.22$ & $16.33 \pm 4.63$ & $14.7 \pm 2.9$ & $15.4 \pm 4.02$ & $16.89 \pm 3.06$ \\
\hline
\end{tabular}

Values are means \pm Standard deviation, $p=0.00$

Key:

$\mathrm{CFU}=$ Colony Forming Units, $\mathrm{SD}=$ Standard Deviation, $p$-value = Probability Value, $=$ Naira

Table 2: Occurrence of Bacteria on Currency Notes obtained from Different Markets $(\%)(\mathbf{N}=\mathbf{8 0})$.

\begin{tabular}{|c|c|c|c|c|c|c|c|c|c|c|c|c|c|c|c|c|c|}
\hline BACTERIA & $\mathbf{S}$ & KW & D & UR & KS & $\mathrm{N}$ & $\mathbf{C H}$ & KK & KB & $\mathrm{KL}$ & TOTAL & $\mathbf{N}$ & $\mathbf{C H}$ & $\mathbf{K K}$ & KB & $\mathbf{K L}$ & TOTAL \\
\hline $\begin{array}{l}\text { Staphylococcus } \\
\text { aureus }\end{array}$ & $6(40.9)$ & $6(60)$ & $4(50)$ & $3(50)$ & $2(50)$ & $3(50)$ & $2(50)$ & $2(50)$ & $5(62.5)$ & $2(66.7)$ & $35(52.2)$ & $3(50)$ & $2(50)$ & $2(50)$ & $5(62.5)$ & $2(66.7)$ & $35(52.2)$ \\
\hline Proteus. Spp & $2(1.0)$ & $1(10)$ & - & - & - & - & - & - & - & - & $3(45 \%)$ & - & - & - & - & - & $3(4.5)$ \\
\hline $\begin{array}{l}\text { Salmonella } \\
\text { species }\end{array}$ & $2(1.0)$ & $1(10)$ & $2(15)$ & $1(16.7)$ & - & - & - & $1(25)$ & $1(12.5)$ & - & $8(11.9)$ & - & - & $1(25)$ & $1(12.5)$ & - & $8(11.9)$ \\
\hline E. Coli & $4(28.6)$ & $2(20)$ & $2(15)$ & $2(33.3)$ & $2(50)$ & $3(50)$ & $2(50)$ & $1(25)$ & $2(25)$ & $1(12.5)$ & $21(31.3)$ & $3(50)$ & $2(50)$ & $1(25)$ & $2(25)$ & $1(12.5)$ & $21(31.3)$ \\
\hline TOTAL & $14(21)$ & $10(15)$ & $8(12)$ & $6(8.9)$ & $4(5.9)$ & $6(8.9)$ & $4(5.4)$ & $4(5.4)$ & $8(12)$ & $3(4.5)$ & $67(83.8)$ & $6(8.9)$ & $4(5.4)$ & $4(5.4)$ & $8(12)$ & $3(4.5)$ & $67(83.8)$ \\
\hline
\end{tabular}

Key : S= Sabo, KW=Kawo, D=Dattawa, UR=Unguwan rimi, KS=Kasuwan sati, $\mathbf{N}=\mathbf{N a s a r a w a , ~ C H = C h e c e n i y a , ~ K K = K a k u r i , ~ K B = K a s u w a n}$

barci, KL=Kasuwan laraba, - Not detected 
Special Conference Edition, November, 2019 DISCUSSION

All the currency notes analyzed in this study had high significant counts. This could probably be due to commercial activities peculiar to all the markets which involved major beverage depots, major motor parks, numerous food items sold and the unhygienic ways of handling paper currencies by the traders, leading to possible sources of contamination of currencies with different types of pathogenic bacteria (Basavarajappa et al., 2005). This is in agreement with the work of Mukharjee et al. (2017) who stated that paper currencies can act as vehicles for transmission of pathogenic microorganisms and with the work of Elemam et al. (2016), where the pathogens observed were attributed to keeping money in dirty places and as a habit, wetting fingers with saliva while counting currency notes. Additionally, unwashed fingers contain many microorganisms, which could be transient or resident. Other practices, include indiscriminate coughing, sneezing and defecation while holding currency notes which could pose some health hazards (Elemam et al., 2016).

Currencies with higher mean bacterial counts were the lower denomination notes. This might be because lower denomination currency notes may carry more of infectious agents since they rate high in circulation than higher denominations as stated by Alemu (2014). The result also agrees with the work of Elemam et al. (2016) who stated that, currency notes of lower denominations are highly contaminated because they are mostly used for daily transactions. Other factors include long time use, duration or storage conditions and the materials used to produce the notes which may influence the load of microbial contamination (Alemu, 2014).

However, our result contradicts similar work conducted by Stanley et al. (2014) who showed that, smaller currency notes of lower denominations contain relatively lower bacterial load than the higher paper notes.

Of the four different types of bacterial species isolated, Staphylococcus aureus was the most

\section{REFERENCES}

Alemu, A. (2014). "Microbial Contamination of Currency Notes and Coins in Circulation: A Potential Public Health Hazard. Biomedicine and Biotechnology. 2(3): 4653.

Basavarajappa, K., Rao, P., and Suresh, K. (2005). Study of bacterial, fungal, parasitic contamination of currency notes in frequently encountered bacteria. This result supported the previous study of Rongpharpi et al. (2013), who reported similar isolates of bacteria. The presence of Staphylococci is usually indicative of contamination from the skin, mouth, or nose or due to rub off from humans, as the organism is a normal flora of the human body. However, some strains of Staphylococcus species including coagulase-negative, can cause a number of diseases (Lakhundi and Zhang, 2018).

The presence of enteric bacteria such as coliforms and Escherichia coli has been widely accepted as an indicator of fecal contamination which may be attributed to the possibility that many people disregard hand washing after using toilets indicating that paper currencies can act as potential sources of enteric diseases (Elemam et al., 2016). Such findings are also in line with what was reported by Enemour et al., (2012) that currency notes are contaminated with enteric pathogens and certain strains associated with the intestine (Staphylococcus aureus, Klebsiella pneumonia and Enterobacter species) may cause oral and dental healthcare-associated infections.

In this study, Salmonella species and Proteus species were less prevalent $(11.9 \%$ and $4.5 \%)$ probably due to certain growth factors

\section{CONCLUSION}

In conclusion, all samples of currency notes collected from the different markets studied were highly contaminated with bacteria. Four different types of bacteria were isolated from the samples of currencies analyzed. Staphylococcus aureus was the most frequently encountered bacteria $(52.8 \%)$, followed by Escherichia coli $(31.3 \%)$, Salmonella species $(11.9 \%)$ and Proteus species $(4.5 \%)$. The overall prevalence is $84.3 \%$. The presence of these bacteria on the currencies circulating within the various markets poses some health hazards on the users. Therefore, general handling of currency notes deserve special attention by their users as they are vehicles of transmitting diseases.

circulation. Indian Journal of Pathogenic Microbiology. 48: 27-80.

Debajit, B., Awe, S., and Al-Ghamdi, A. K. (2012). Paper currencies: A potential carrier of pathogenic microorganisms. International Journal of Applied Biology and Pharmaceutical Technology. 3: 2325. 
Special Conference Edition, November, 2019

Elemam, M.M., Dhawi, A., Ben Shaban, M., and Dahmani, M. (2016). A Study of Bacterial Contamination on Libyan Paper Banknotes in Circulation. American Journal of Microbiology and Biotechnology. 3, (1):1-6.

Enemour, S.C., Victor, P. I., and Oguntibeju, O.O. (2012). Microbial contamination of currency counting machines and counting room environment in selected commercial banks. Science Research. 1501-1511.

Kramer, A., Schwebke, I., and Kampa, G. (2013). How long do nosocomial pathogen persist on inanimate surfaces? A systematic review. BMC Infectious Diseases. 6: 130

Kuria, J. K., Wahome, R. G., Jobalamin, M. and Kariuki, S. M., (2009). Profile of bacteria and fungi on money coins. East African Medical Journal. 86: Pp 151-155.

Lakhundi, S., Zhang, K. (2018): Methicillin Resistant Staphylococcus aureus: Molecular Characterization, Evolutionand Epidemiology. Clinical Microbiology Reviews. 10: 00020-18.

Michael, B., (2013). Handling money and serving ready to eat food. Journal of Food Service Technology, 2: 1-3.

Michael, B., Ganger, V., Lin, V., and Doyle, M. (2013). Use of Alcoholic Instant Hand Sanitizer as Part of a Food Service Hand Hygiene Programme. Food Service Technology. 3: Pp 71-80.

Mukharjee, S. K., Hossain, S., and Saifur Rahman, Md. (2017). Evaluation of Bacterial
Contamination and Safety of Bangladeshi Paper Currencies (Taka) Collected from Various Food Vendors. Journal of Advances in Microbiology. 4(2): 1-9.

Okwa, O.O., and Bello, S.A. (2016). Parasitic organisms on Nigerian currency notes in Ojo Local Government, Lagos, Nigeria. International Journal of Pure and Applied Zoology. 4(2): 221-224.

Olise, C.C., and Simon-Oke, I.A. (2018). Fomites: Possible vehicle of nosocomial infections. Journal of public health catalog. 1(1):1618

Prasai, T., Yami, K.D., Joshi, D.R. (2013). Microbial load on paper/polymer currency and coins. Nepal Journal of Science Technology. 9(1): 5-9.

Rongpharpi, S.R., Hazariki, N.K. and Kalita, H. (2013): The Prevalence of Nasal Carriage of Staphylococcus aureus Among Health Care Workers at Tertiary Care Hospital in Assam with Special Reference to MRSA. Journal of Clinical Diagnostic Research. 7(2):257-60.

Stanley, M.C., Ifeanyi, O. E., Nwosu, D.C., and Ejiofor, A. C. (2014). Microbiological Evaluation of Naira Notes Handled by Fish Sellers in Umuahia Metropolis. World Engineering \& Applied Sciences Journal. 5(2): 44-52.

Xu. J., J. Moore., and Millar. B.C. (2013). Ribosomal DNA (rDNA) identification of the culturable bacterial flora on monetary coinage from 17 currencies. Journal of Environmental Health. 67: 5155. 